\title{
Online Learning and Face-to-Face Learning in the COVID-19 Pandemic in SMA Erlangga Pematangsiantar
}

\author{
Ahmad Fakhri Hutauruk ${ }^{1}$, Sariaman Gultom ${ }^{2}$, Ahmad Arif Budiman Nasution ${ }^{3}$ \\ ${ }^{1,3}$ History Education Study Program, Universitas Simalungun, Indonesia \\ ${ }^{2}$ Pancasila and Civic Education Study Program, Universitas Simalungun, Indonesia \\ fakhrispd@gmail.com
}

\begin{abstract}
This study aims to explore online and face-to-face learning (class) so that it can be effective, and the curriculum objectives are met. The nature of this research is qualitative phenomenology to be able to find out the extent of the application of learning that has been carried out online and face-to-face at SMA Erlangga Pematangsiantar, North Sumatera. The research mechanism includes the planning, implementation, observation, and reflection stages. The research results found several obstacles in terms of implementation but in general, the teacher can overcome them well. During a pandemic, a teacher's creativity is highly tested by the learning he does both in online and face-to-face systems so that learning success can be achieved. Finally, this research gives the result that by comparing the learning system, the teacher actually wants direct (face-to-face) pursuit so that it is easier in the process of interactive communication with students, and student motivation also increases in classroom learning because of direct interaction.
\end{abstract}

Keywords online class, face to face; covid-19 pandemic period

\section{Introduction}

Education in this case the school is an institution that is required to develop the skills and character of students. Education is also interpreted as a procedure in creating a complete human being. Through education, we sprinkle ways of thinking, character, and values that the community believes in (Hartiwi et al, 2020). Conscious and structured activities in delivering assistance and guidance in increasing children's potential, both physically and spiritually, which parents send to their children for the sake of providing their children in the future to become human beings who are faithful, knowledgeable, noble, creative, and independent who can live in the middle -the middle of society. Education will provide lessons listed in the National Education System Law No. 20 of 2003 Article 3 which states that the goal of national education is to develop the potential of students to become human beings who believe in and fear God Almighty, have noble moral values, are healthy, and are democratically independent. (Mukartik et al, 2020; Apriani et al, 2020; Amalia, 2019).

The world was shocked by the emergence of the Covid-19 virus which started in the city of Wuhan, China. Then quickly spread throughout the world, until finally determined by the $\mathrm{WHO}$ as a pandemic. The impact of this virus is quite dire, namely causing death, but the most troublesome thing is human-to-human transmission so that its handling has sparked an uproar for all countries (Zulaiha et al, 2020). The interactions that humans usually do begin to adapt during the pandemic, a new habit system (new normal) is implemented. In breaking the chain of spreading Covid-19 with social distancing (keep your distance). The prohibition of crowds and mass gathering has hampered many occupations and activities. Schools are a forum that triggers an association of people who 
are greatly affected during this pandemic. The emergence of regulation from the minister of education regarding the prohibition of teaching and learning activities in schools and replaced with an online classroom system as a solution to the vacuum of learning during this pandemic. The use of technology becomes an alternative media for learning. However, many obstacles occur with the pursuit of this online classroom system where the students' ownership and mastery of technology are not evenly experienced, the supporting facilities and infrastructure seem to be rushed if arguably not ready at all to the inconsistent motivation of both teachers and students because this distance learning system. Komalasari et al, 2020; Fitria and Suminah, 2020; Hamzah et al, 2020; Rohma et al, 2020). The development of technology, communication and information, especially the internet has become a demand for teachers in Indonesia to be able to use it as a source of positive learning media in supporting teaching and learning processes (Prasasti in Ediyani et al, 2020).

It is worth noting that the use of the term online is suddenly becoming common nowadays and perhaps many do not know, namely the teaching-learning system which is carried out online with the use of a computer, laptop, or smartphone-based on internet usage. So that does not mean distance learning using physical paper and then delivered to home and school can be said to be an online learning system. (Ivanova et al, 2020). This also adds to the problem because additional costs are required to buy an internet package, plus the economic conditions that are currently in shock are increasingly burdensome for the parents of students to meet these demands. There is indeed government assistance regarding the provision of data packages for both educators and students, but the network is slow and does not support virtual application support. Many virtual application platforms have emerged, such as Google Classroom, Google Meet, Zoom, and others. But once again the readiness of teachers and students is still lacking due to the tendency to be less focused during the use of the platform.

There are various ways that schools can carry out learning to fill in the gaps caused by obstacles during this pandemic, both using online or face-to-face learning. So that the delivery of material can be conveyed properly to students. In this case, it is an effort to keep the students educated properly. (Soleh et al, 2019; Septiani and Cahyono, 2019; Nugraha, 2019).

\section{Research Methods}

This research is qualitative research with the type of phenomenological method, where this research aims to see the phenomena that exist in life in society, the phenomenological method explores data in finding essential phenomena such as the experiences of a researcher. What is meant by the research method is a scientific method for a way to find, obtain, conclude, or record data, both primary and secondary which are used to compile scientific papers. (Sugiyono, 2017). So the goal is to find out how the online and face-to-face learning system at SMA Erlangga Pematangsiantar. Where the sample is 11 teachers at the school. The steps of this research include planning action, implementing, observing, and reflecting.

\subsection{Action Planning}

At this stage, the researcher explains about $4 \mathrm{~W} 1 \mathrm{H}$, namely what, when, where, why, and why. Classroom action-based research will be carried out collaboratively to reduce the risk of the subjectivity of research results. At the research stage, there will be actions to assess yourself, namely when the researcher makes an approach, model, or learning method to solve problems during practice in the field. The existence of peers is 
needed to evaluate these activities. In the planning stage, the researcher also realizes that there is a need for explanations related to the preparations for conducting research, such as lesson plans and observation instruments. In planning the action during the Covid-19 period, teachers were given various choices of educational units in special conditions according to the guidelines for implementing the curriculum according to the instructions of the minister of education including a) continuing to use the national curriculum b) using the emergency curriculum c) making and simplifying the curriculum itself. In this study, SMA Erlangga used an emergent curriculum by the mandate from the Minister of Education.

\subsection{Execution of Actions}

At the implementation stage, the implementation of action plans is carried out. In the implementation activity, the teaching staff (teachers) must be ordered with the plans that have been prepared. The most important thing and need to be considered at this stage is learning must continue to run as normal, should not be made up and stiff. Collaborators strive to make observations objectively according to the learning conditions carried out by the researcher. This activity is important because the purpose of classroom action research is to improve the learning process.

\subsection{Observation Stage}

In the observation stage, there are two activities to be observed, namely student learning activities and learning activities. Observation of the learning process, the implementing teacher (researcher) while carrying out the learning, while the observation of the learning, namely the learning activities of students and learning activities. Observation of the learning process of students can be carried out by implementing teachers (researchers) who can ask for help from colleagues who act as collaborators to make observations. Collaborators make learning observations based on instruments that have been prepared by the researcher. The results of observations from collaborators will later be useful or will be used by researchers as material for reflection to improve subsequent learning. During the observation, it was seen that the teacher and students were more interested in face-to-face learning than the online classroom system because of the difficulty of the teacher in supervising and guiding each student.

\subsection{Reflection}

Finally, the reflection activity is carried out when the collaborator has finished observing the researcher while carrying out the learning. This activity can be in the form of a discussion of the results of observations made by collaborators with researchers. This stage is the core of classroom action research when the collaborator describes things that have gone well and parts that have not worked properly at the time of the research. The results of the reflection can be used as consideration in designing the next cycle. So in essence, reflection is an activity of evaluation, analysis, interpretation, explanation, conclusion, and identification of follow-ups in planning the next cycle.

Data collection techniques in this study use interview techniques to obtain information about the difficulties faced by teachers when teaching in online or face-to-face classes, observation is also used to observe the implementation of online classroom learning, and face-to-face learning is carried out to obtain validity data from the implementation of classroom learning. online and face-to-face learning. The indicator of the success of this research is that students get good criteria. The object of this research is 11 teachers at SMA Erlangga Pematangsiantar, North Sumatera. Where the time is carried out for 2 weeks from 18-30 January 2021. 


\section{Results and Discussion}

The results of this research will be discussed in the following chapter. Where this research was conducted at SMA Erlangga Pematangsiantar, where the school has held online classroom learning and face-to-face learning based on health protocols in the odd semester of the 2020/2021 school year.

The procedure for implementing online class assignments, namely the duties of the principal 1) The principal assigns educators to carry out learning activities at home according to the class or subjects on the roster through social media platforms 2) distributes circular letters to parents about learning management at home (online classes) to secure the health conditions of students to stay at home. 3) socializing to students regarding online learning media and procedures for using the media; 4) control and supervise the implementation of learning at home that has been assigned to the teacher; 5) make a report on the results of learning activities at home.

The student's task is to discuss material or subject-matter uploaded by the teacher through predetermined media. Students can have discussions with the teacher regarding their lack of understanding of the learning material.

Parents here are also given a role in the success of this online classroom learning by 1) monitoring their child's learning activities in their respective homes and limiting activities outside the home; 2) actively coordinating with homeroom teachers, teachers, or schools; and 3) guide students to exercise diligently, eat nutritious food and reduce stress. While the steps that must be prepared face-to-face learning, namely pre-learning 1) prepare RPP; 2) prepare to teach materials, schedules and assignments then send them to students/parents/guardians; 3) ensure that all students have received a schedule and assignment sheet; 4) teachers and parents/guardians of students meet to submit schedules and assignments based on health protocols, namely washing hands, wearing masks, maintaining distance; 5) learning schedules and learning assignments are taken by the parents/guardians of the students once a week at the end of the week and/or disseminated through the available communication media.

Starting learning, 1) face-to-face learning assisted by parents/guardians of students according to the schedule and assignments that have been given; 2) the teacher can make visits to students' homes to check and study assistance. If this is done, it is mandatory to follow health protocols and 3) pray together before and after studying.

End of learning 1) each student fills in an activity sheet as material for daily learning monitoring; 2) the parents/guardians of the students sign each completed learning session on the daily monitoring sheet; 3) assignments are given according to the schedule; 4) The results of the assignment and daily activity monitoring sheets are collected every week as well as taking schedules and assignments for the following week. It can also be sent using communication; and 4) the content of the assignment is life skills education, including regarding the Covid-19 pandemic.

The implementation of online and offline learning systems inevitably has to be done amid the Covid-19 outbreak. Because students cannot be left on a long holiday until they wait for Covid-19 to disappear. In online and offline learning at this school during the Covid-19 pandemic, there were several obstacles such as limited time for learners because learning time was reduced so that the material conveyed was not complete. For offline learning, the weaknesses are that it is constrained by the slow internet and limited internet quota (Risdianto et al, 2020). 
In learning during the Covid-19 pandemic, this school used various ways to keep the learning going, such as using online learning first by using various social media platforms such as the WhatsApp, Google Classroom, Google Meet, and Zoom applications. For the learning process to run smoothly the teacher must provide direction first, in online classroom learning students prefer it because the presentation of the material is more attractive, thus attracting students' interest to review the material more deeply. However, sometimes there are obstacles such as finding students who do not do assignments on the pretext of not having supporting technology facilities such as Android because the parents of these students do not have money or there is only one at home so they take turns with other families, there is no signal in where they live, and the absence of adequate credit. Due to these constraints, this school tries to use face-to-face learning but students are limited to attending, which is half of the class, which consists of 40 students, so only 20 students are present who are divided based on odd and even according to absences. In this learning process, the learning time is also limited to one lesson hour to only 30 minutes, but the school also does not force students to choose face-to-face learning because some students are not allowed by their parents due to the pandemic, so the percentage of those who do learning is approximately $98 \%$.

So when viewed based on the online or face-to-face learning process carried out in this school, the teacher factor is very large in the success of learning. Although there are many alternative media related to face-to-face replacement systems. The learning process in the classroom is very much determined by the teacher so that in the future this effort can continue so that the Covid-19 link can be broken and things return to normal.

\section{Conclusion}

Since the emergence of Covid-19 and the widespread and exposure of victims, schools and other educational institutions can no longer carry out teaching and learning activities, as usual, this is related to the ban on mass gathering and maintaining a distance that the government campaigned to break the chain of spreading the virus. Learning is diverted at home, one alternative step in overcoming this problem is to use internet social media technology, with many platforms as a forum for online classes but when the implementation of learning begins to emerge obstacles are found by teachers where online learning is an online class. This is the first time this has been done as constrained by internet signal and quota, completeness of learning tools such as smartphones. However, these obstacles are not a barrier to educating students, as time goes by, the government allows schools to reopen learning in schools with strict application of health protocols, so face-to-face learning is created. Every lesson sometimes has advantages and disadvantages, including online classroom learning and face-to-face disgust during the Covid-19 pandemic, however, from the online and offline learning systems, it is hoped that teachers will be creative in educating students. So that the success of learning can be achieved properly or effectively. The reference is the completeness of the national curriculum 


\section{References}

Amalia, D. (2019). Promoting Just Culture For Enhancing Safety Culture In Aerodrome Airside Operation. International Journal of Scientific \& Technology Research 8 (10)

Apriani, N., Fatonah, F., \& Oka, I. A. M. (2020). Rancangan Sistem Pengolahan Sertifikat Berbasis Website Sebagai Upaya Untuk Peningkatan Evaluasi Kompetensi Safety Personil Di Lingkungan PT Angkasa Pura II (Persero). Langit Biru: Jurnal Ilmiah Aviasi, 17-28.

Ediyani, M., et al. (2020). Study on Development of Learning Media. Budapest International Research and Critics Institute-Journal (BIRCI-Journal). P. 1336-1342.

Fitria, H., \& Suminah, S. (2020). Role of Teachers in Digital Instructional Era. Journal of Social Work and Science Education, 1(1), 70-77.

Hamzah, S., Yussof, M. H. B., \& Enriquez, A. A. (2020). Togetherness in the Diversity of the Pancasila Ideology Frame. Journal of Social Work and Science Education, 1(1), 8-12.

Ivanova, T., Gubanova, N., Shakirova, I., \& Masitoh, F. (2020). Educational technology is one of the terms for enhancing public speaking skills. Universidad y Sociedad, 12(2), 154-159.

Komalasari, K., Arafat, Y., \& Mulyadi, M. (2020). Principal's Management Competencies in Improving the Quality of Education. Journal of Social Work and Science Education, 1(2), 181-193

Kristiawan, M. (2014). A Model for Upgrading Teachers Competence on Operating Computer as Assistant of Instruction. Global Journal of Human-Social Science Research.

Kristiawan, M., \& Muhaimin, M. (2019). Teachers' Obstacles In Utilizing Information and Communication Technology. International Journal of Educational Review, 1(2), 56-61.

Murkatik, K., Harapan, E., \& Wardiah, D. (2020). The Influence of Professional and Pedagogic Competence on Teacher's Performance. Journal of Social Work and Science Education, 1(1), 58-69

Nugraha, W. (2019) Safety Documentation: A Communication Approach For Safety Management System In Aerodrome Operator. International Journal of Scientific \& Technology Research 8 (11), 1705-1711

Prasasti, T.I., et al. (2019). The Effectiveness of Learning Media Folklore Text of North Sumatera Based on Blended Learning by 10th Grade Students of Vocational High School Harapan Mekar-1 Medan. 480-490

Risdianto, E., Fitria, J., Johan, H., \& Macariola, J. S. (2020). Teacher's Perception of Thermodynamic Law Module Developed in Training through Student's Critical Thinking Skills. Journal of Social Work and Science Education, 1(1), 78-86.

Rohma, S., Harapan, E., \& Wardiah, D. (2020). The Influence of School-Based Management and Teacher's Professionalism toward Teacher's Performance. Journal of Social Work and Science Education, 1(1), 13-23.

Septiani, V., \& Cahyono, D. (2019). Education and Training Strategy in Palembang Aviation College. International Journal of Recent Technology and Engineering, 8 (3)

Soleh, A. M., Tobari., Kesumawati, N. (2019). Development of The Practical Manual As A Learning Media For Simulator Aircraft Rescue And Fire Fighting. International Journal of Scientific \& Technology Research 8(10).

Republik Indonesia. (2013). Undang-Undang Sistem Pendidikan Nasional No 20 tahun 2003. Sekretariat Negara. Jakarta

Sugiyono. (2017). Metode Penelitian Kuantitatif, Kualitatif, dan R\&D. Bandung: Alfabeta.

Zulaiha, D., Lian, B., \& Mulyadi, M. (2020). The Effect of Principal's Competence and Community Participation on the Quality of Educational Services. Journal of Social Work and Science Education, 1(1), 45-57. 
